PRINT ISSN 1119-8362

Electronic ISSN 1119-8362
Full-text Available Online at https://www.ajol.info/index.php/jasem http://ww.bioline.org.br/ja

\title{
Proximate and Elemental Analysis of African Star Apple (Chrysophyllum albidum)
}

\author{
*IBRAHIM, H; HARUNA, A; ABDULLAHI, N
}

\author{
Department of Chemistry, Ahmadu Bello University, Zaria, Nigeria \\ *Corresponding Author E-mail: hibrahimbk@yahoo.com; Tel: +2348035921849
}

\begin{abstract}
The proximate and elemental analysis of African star apple (Chrysophyllum albidum) using standard analytical techniques was investigated. The proximate composition of the plant showed the values of $54.57 \%$ for carbohydrate, $13.25 \%$ of fat, and $3.85 \%$ of crude protein. The crude fiber and ash content indicates the values of $6.60 \%$ and $4.70 \%$ respectively. The moisture content present $(17.03 \%)$ reveals the possibility of having low antimicrobial activities of the plant. The mineral elements present in different concentrations are $\mathrm{Ca}(706.850 \mathrm{mg} / \mathrm{kg}), \mathrm{Mg}(325.500$ $\mathrm{mg} / \mathrm{kg}), \mathrm{Fe}(40.875 \mathrm{mg} / \mathrm{kg}), \mathrm{Cu}(3.275 \mathrm{mg} / \mathrm{kg})$, and $\mathrm{Zn}(4.625 \mathrm{mg} / \mathrm{kg})$. The result shows that the fruit have essential minerals required by human for normal life activities.
\end{abstract}

DOI: $\underline{\text { https://dx.doi.org/10.4314/jasem.v25i2.18 }}$

Copyright: Copyright $(92021$ Ibrahim et al. This is an open access article distributed under the Creative Commons Attribution License (CCL), which permits unrestricted use, distribution, and reproduction in any medium, provided the original work is properly cited.

Dates: Received: 12 December 2020; Revised: 26 January 2021; Accepted: 12 February 2021

Key words: Chrysophyllum albidum, Star apple, Proximate compositions, Mineral elements

The use of medicinal plants to cure ailments is on the increase in Africa and is recently drawing tremendous attention in the field of phytochemistry. Generally, plants are primary source of medicine, food, shelters and other items used by humans every day of their lives. Their roots, stems, leaves, flowers, fruits and seeds provide food for humans and other animals (Amaechi, 2009). The plant, African star apple (Chrysophyllum albidum) belong to the family of sapotaceae and the class ericales. It is a widely grown plant in the southwestern part of Nigeria commonly known as "Agbalumo" (Yoruba), "Udara" (Igbo) and "Agwaluma" (Hausa) in the Nigerian main local languages. The plant was reported to having excellent source of vitamins, irons, flavors to diets and raw materials for manufacturing industries (Adisa, 2000; Bada, 1997; Okafor and Fernandes, 1987; Umelo, 1997). African star apple in recent times, has become a crop of commercial value in Nigeria. Fruits are source of minerals, fiber and vitamins which also provide essential nutrients for human health (Deokule, 2009). Some fruits are known to have anti-nutritional factor such as phytate and tannins which can diminish the nutrient bioavailability if present at high concentration. The anti-nutritional factors could also help in the treatment and prevention of several important diseases like the anti-carcinogenic activity of phatic acid that has been demonstrated by in vitro and in vivo assay (Deokule, 2009). The African star apple fruit is a large berry containing 4-5 flattened seeds or sometimes fewer due to seed abortion (Keay, 1989). The plant has been observed to having efficient recycling ability, being an evergreen tree that rarely sheds all its leaves in any one season except when it is dead or under stress. The ripe fruits is available anytime from January through April in the southwestern part of Nigeria. Locally, the variation of the fruit exocarp color is said to be correlated with the pulp taste. The exocarp of the sweet fruits are yellow while that of the sour ones have a mixture of yellow and green colors when matured. The secondary metabolites present in the leaves of the plants are used in the treatment of various ailments as previously reported (Issac et al., 2015). The fleshy pulp of the fruit is eaten especially as snacks and realized by both young and old because of its high nutritional value (Cendard, 1999). The seeds are used for local games by children as whistle. The fleshy and juicy fruits which are popularly eaten, are the potential source of soft drinks. The fruit are also suitable for the production of fruit jams and jellies. Okafor and Fernendes (1987), reported an excellent source of vitamins, irons, flavors to diets and raw material for some manufacturing industries. The back foliage and fruit of some Chrysophyllum species are also used for traditional medicine. The African star apple is produced commercially in West Africa (Amusa et al., 2003). Ecologically, the tree has an efficient nutrient cycling and the high rate of mineralization of the leaves improves the quality of top soil (Egunyomi and Oladunjoye, 2012). Studies shows that fruit pulp of the plant contains $21.8 \mathrm{mg} / 100 \mathrm{~g}$ ascorbic acid and the skin contains $75 \mathrm{mg} / 100 \mathrm{~g}, 446 \mathrm{mg}$ and $239 \mathrm{mg} / 100 \mathrm{~g}$ for the pulp and skin respectively (Edem et al., 2011). 
The fruit is said to contain a hundred times more vitamins $\mathrm{C}$ than oranges and ten times that of guava. Ukana et al., (2012), reported the proximate compositions and the mineral elements in the star apple peel, pulp and seed. The results from the proximate composition showed that star apple peel, pulp and seed have greater amount of carbohydrate contents. The mineral element composition revealed that the peel contains greater amount of potassium and zinc while, the pulp contains greater amount of sodium and iron, calcium and magnesium were high in the seed of the fruits. Hence, each of these samples (peal, pulp and seed) can act as a source of the mineral supplement in food and allied industries. The aim of this study was to investigate the proximate composition and to analyze the mineral elements presents in the African star apple. Also, to determine the moisture and ash contents, crude fat, crude fiber, and crude protein contents and to calculate the total carbohydrate content of the African star apple.

\section{MATERIALS AND METHOD}

Sample collection: Fresh samples of African star apple (Chrysophyllum albidum) (Figure 1) were obtained from Samaru market in Zaria, Kaduna State-Nigeria. The fruits were sorted, cleaned and washed thoroughly to remove presupposed dirt. The fruits were opened to remove all the seeds and the peels, and then the pulps were spread on trays for drying at room temperature of $25^{\circ} \mathrm{C}$. The dried samples were grounded into flour and the flours were packaged in air tight plastic container prior to use. The moisture and ash contents are determined using the fresh fruits samples while the dried pulped samples were used for the determination of proximate composition and elemental analysis. Analytical grade anhydrous sodium sulphate $\left(\mathrm{Na}_{2} \mathrm{SO}_{4}\right)$, cupper (II) sulphate, sulphuric acid, hydrochloric acid, sodium hydroxide, methyl red indicator, boric acid, N-hexane, nitric acid, ethanol and potassium sulphate purchased from SigmaAldrich chemical company were used without further purification. Deionized water was used throughout in the experiment.

Proximate composition: The moisture content, ash content, crude protein and crude fat were determined in accordance with Association of Analytical Chemist (AOAC, 1990), while crude fibre was determined using (AOAC, 1995). Carbohydrate content was determined as the difference obtained after subtracting the values in percentage of crude protein, lipid ash, and fibre from the total dry matter.

Digestion of sample: Some $2.0 \mathrm{~g}$ of the sample was weighed into Kjeldahl flask. About $5.0 \mathrm{~g}$ anhydrous sodium sulphate or 4 tablets of kjeldahl catalyst was added and then $5 \mathrm{ml}$ of concentrated $\mathrm{H}_{2} \mathrm{SO}_{4}$ was added. The digestion flask was placed in the digestion rack and heated gently to avoid frothing for 2 hours until a clear bluish solution was obtained. The digest was allowed to cool to room temperature and was transferred into a volumetric flask $(250 \mathrm{ml})$ and made up to the mark with distilled water.

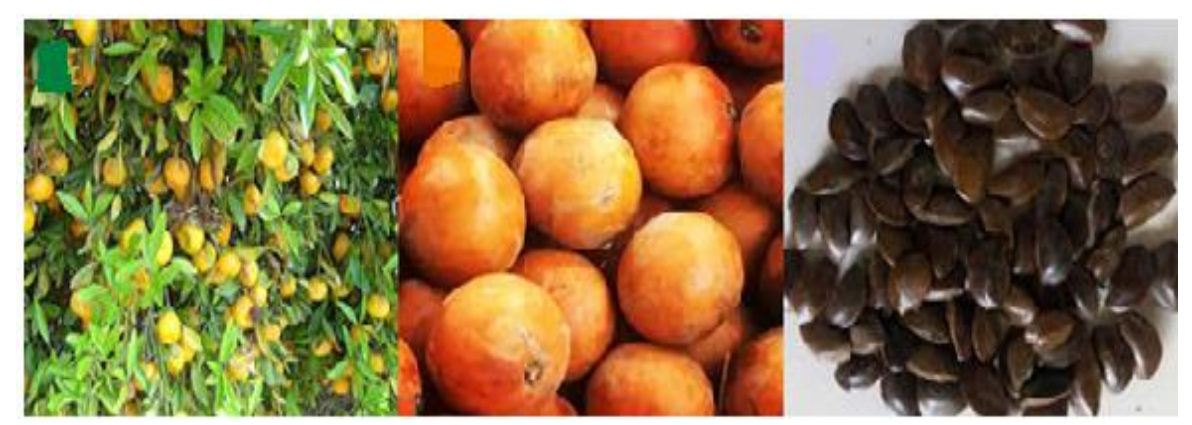

Fig 1: Different part of African star apple showing the plant, leaves, fruits and seed

Elemental analysis: The elemental analysis was determined by using atomic absorption spectroscopy (AAS) by means of digestion. Aqua regia digestion is an effective way of digesting under wet digestion. Digestion is a process of separating of element of interest from organic matter. According to this method, a mixture of $\mathrm{HCl}$ acid and $\mathrm{HNO}_{3}$ in the ratio of 3:1 known as aqua regia mixture was used for the digestion process. Conventional aqua regia digestion was performed in $250 \mathrm{ml}$ glass beakers covered with watch glasses. A well-mixed sample of $2 \mathrm{~g}$ was digested in $24 \mathrm{ml}$ of aqua regia on a hot plate for 20 minutes at $110{ }^{\circ} \mathrm{C}$. It was evaporated to near dryness and the sample was diluted with $20 \mathrm{ml}$ of $2 \%$ (V/V with water) nitric acid and transferred into a $50 \mathrm{ml}$ volumetric flask after filtering through a what man no 42 paper and then diluted to $50 \mathrm{ml}$ with DDW, then transferred the filtrate into $50 \mathrm{ml}$ sample bottle.

\section{RESULTS AND DISCUSSION}

The result of proximate analysis of the African star apple fruit is presented in Figure 2. The moisture 
content of any food is an index of its water activity (Frazier et al, 1978) and is use as a measure of the stability and susceptibility to microbial contamination. The moisture content of the fruit was determined to be $17.03 \%$ which is lower than $42.1 \%$, a value earlier reported for the same fruit (Amusa et al., 2003). The low moisture content also implies that dehydration will decrease the relative concentration of the other food nutrient and improve the long shelf-life the fruits (Edem et al., 2008). The crude fat (13.25\%) observed for the fruit is lower than $(16.20 \%)$ earlier reported for the same fruit (Amusa and Oladapo, 2003) but higher than $(11.7 \%)$ crude fat content reported for averrhoa carambola fruit (Edem et al., 2009) and also higher than $(7.0 \%)$ and $(4.0 \%)$ reported for S. agilo and S. aubergina fruits respectively (Edem et al.,1978). The results indicates that $C$. africanum contain a high amount of crude fat. The ash content of $C$. africanum fruit obtain in this study was found to be $4.70 \%$. This value is higher than $(2.95 \%)$ earlier reported for the same fruit (Amusa and Oladapo, 2003). It is also higher than $3.50 \%$, a value reported for A. carambola fruit (Edem et al., 2008). The protein content of $C$. africanum fruit obtained from the analysis was only about $(3.85 \%)$ and is lower in amount than $(8.75 \%)$ earlier reported for the same fruit (Amusa et al., 2003). The value is also lower than $(14.87 \%)$ and $(15.75 \%)$ reported for S.agilo and S.aubergine fruits respectively (Edem et al., 2009). This result shows that $C$. africanum fruit is very low in its protein content this and the value can be improved by the dehydration of the fruit (Igboh et al., 2009). The crude fibre of $C$. africanum fruit $(6.60 \%)$ obtained from the analysis is higher than that earlier reported for the same fruit (Amusa and Oladapo, 2003). This value is lower than $(8.60 \%)$ reported for A. carambola fruit (Edem et al., 2008). The value is also lower than $(16.0 \%)$ and $(11.75 \%)$ reported for $S$. agilo and S. aubergine fruits respectively (Edem et al., 2009). The crude fibre content of $C$. africanum fruit can be increased by the dehydration of the fruit, the consumption of fruit with high crude fibre content may contribute to a reduction in the incidence of certain diseases like colon cancer, coronary heart diseases diabetes, high blood pressure, obesity and other digestive disorders (Igboh et al., 2009). Increased crude fibre consumption also increase fecal bulk and rate of intestinal transit and may result in prebiotic effects (Igboh et al., 2009). The carbohydrate content $(54.57 \%)$ obtained for $C$. africanum fruit is lower than $(67.60 \%)$ earlier reported for the same fruit (Amusa et al., 2003). This value is much lower than $(72.20 \%)$ reported for $A$. carambola fruit (Edem et al., 2008).

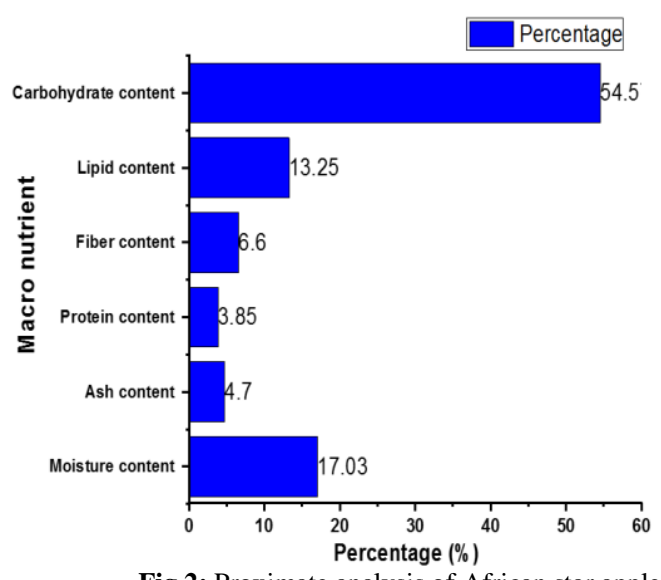

Fig 2: Proximate analysis of African star apple

The mineral composition of calcium in C. africanum fruit was found to be $706.850 \mathrm{mg} / \mathrm{kg}$ which is lower than the recommended value by WHO (1000.000 $\mathrm{mg} / \mathrm{kg}$ ). The concentration of magnesium in the same fruit was determined to be $325.500 \mathrm{mg} / \mathrm{kg}$ and is higher than the body requirements approved by WHO $(300.000 \mathrm{mg} / \mathrm{kg})$. The amount of iron obtained in the analysis was $40.875 \mathrm{mg} / \mathrm{kg}$ which is relatively higher than the recommended value of $4.200 \mathrm{mg} / \mathrm{kg}$ by WHO. The value obtained for zinc in the analysis was 4.625 $\mathrm{mg} / \mathrm{kg}$ which is considerably lower than the recommended value of $25.000 \mathrm{mg} / \mathrm{kg}$ by WHO. The concentration of copper as determined was 3.275 $\mathrm{mg} / \mathrm{kg}$, a value relatively higher than the recommended value of $0.900 \mathrm{mg} / \mathrm{kg}$ by WHO.

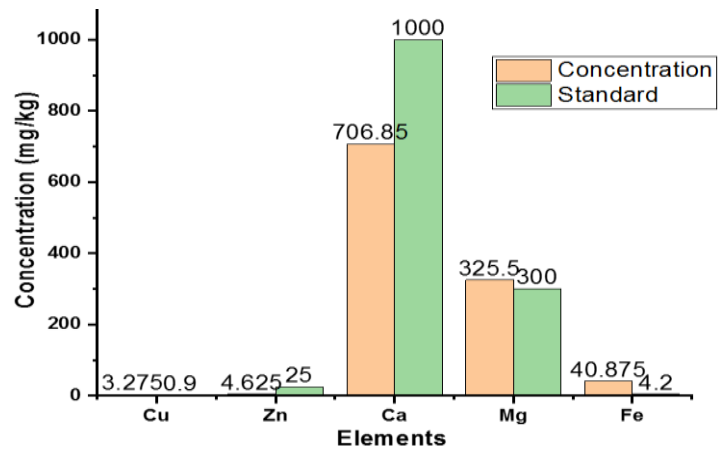

Fig 3: Elemental analysis of the fruits with WHO standard values

Conclusion: African star apple is an edible fruit that is very nutritious and having some medicinal values. Some detailed information on the proximate and certain elemental compositions of Chrysophyllum albidum which enhances our knowledge and appreciation for the use of the fruit in our daily consumptions and as functional health benefits was reported. The Samples were characterized with high carbohydrate content and relatively reasonable amount of minerals ( $\mathrm{Ca}, \mathrm{Fe}, \mathrm{Zn}, \mathrm{Cu}$ and $\mathrm{Mg}$ ). Thus, 
Chrysophyllum albidum could be of high nutritional value and better for consumption.

\section{REFERENCES}

Adisa, SA; Garba SA; Ijagbone, IF; Iyagba, AO; Iyamu, AO; Kilani, AS (2000). Vitamin C protein and mineral contents of African Apple (Chrysophyllum albidum). Proceedings of the $18^{\text {th }}$ Annual Conference of NIST (eds) N.141-146.

Amusa, NA; Ashaye, OA; Oladapo, MO (2003). Biodeterioration of the African star apple (Chrysophyllum albidum) in storage and the effect on its food value. Afr. J. Biotechnol. (2):56-57.

Ameachi, NC (2009). Nutritive and Anti-Nutritive Evaluation of wonderful kola (Buccholziacoricea) seeds. Pak. J. Nutr. 8(8): 1120-1122.

AOAC, (1990). Official methods of Analysis, $15^{\text {th }}$ Edn. Association of Official Analytical Chemists. Washignton, DC. Pp 306-309.

AOAC, (1995). Official methods of Analysis, $15^{\text {th }}$ Edn. Association of Official Analytical Chemists. Washignton, DC. Pp 306-309.

Adebisi, AA; Denton, OA; Ladipo, DO; Adetoro, MB (1997). Preliminary survey of post-harvest and marketing constraints of Chrysophyllum albidum (African Star Apple) in Nigeria. In Proceedings of a National workshop on the potentials of the star apple in Nigeria (eds). (6) 84-102.

Bada, SO (1997). Preliminary information on the ecology of the Chrysophyllum albidum G.Don,in west and Central Africa. In Proceedings of a national workshop on the potentials of the star Apple in Nigeria (eds):16-25.

Batra, J; Seth, PK (2002). Effect of iron deficiency on developing rat brain. Indian J. Clin. Biochem. 17(2): 108-114.

Bender, A (1992). Meat and Product in Human Nutrition in Developing Countries, FAO Food and Nutrition, Food and Agriculture Organization, Rome Italy. (8):53-56.

Cendard, AO (1999). Publication of center for environmental renewable natural resources management, Research and development, jerico, Ibadan publication No CEN 011/1999 85.Pp 86-90.

Deokule, SS; Ali, B (2009). Studies on nutritional values of some wild edible plants from Iran and India. Pak. J. Nutri. 8(1):26-28.
Edem, CA; Christopher, A; Miranda, I (2011). Chemical evaluation of proximate composition, ascorbic acid and antinutrients content of African star apple (Chrysophyllum africanum) fruit. Int. J. Res. Rev. Appl. Sci. (9):1-15.

Edem, CA; Dosunmu, MI; Ebong, AC; Jones, M (2008). Determination of proximate composition of Ascorbic acid and heavy metal contents of star fruit (Averrhoa carambola). Glob. J. Pure Appl. Sci. 14 (2): 193-195.

Edem, CA; Dosunmu, MI; Bassey, FI; Wilson, C; Umeron, P (2009). A Comparative Assessment of the proximate composition, Ascorbic Acid and heavy metal content of two species of Garden Egg solarium gilo and solarium anbergrine. Pak. J. Nutr. 8(8): 582-584.

Egunyomi, AS; Oladunjoye, SO (2012). Studies on the chemical composition and nutritive value of the fruit of African Star Apple. Afr. J. Agric. Res. 7(31): 4256 -42580 .

Frazier, WS; Wwtoff, DC (1978). Food microbiology $3^{\text {rd }}$ edition, McGraw Hill, New York Pp346-348.

Igboh, MN, Ikewuchi, CJ, Ikewuchi, CC (2009). Chemical profile of chomolaena odoratal. Pak. J. Nutr. 8 (5): 521 - 524.

Isaac, KA; Abenaa, AO; Dora, DB; Daniel, OO; Benard, D (2015). Nutritional and phytochemical constituents of the African star apple (Chrysophyllum albidum G. Don). Annals. Food Sci. and Technol. 16 (1): 138 - 146.

Keay, RWJ (1989). Trees of Nigeria. A revised version of Nigerian trees keay R. W. J, Onoche CFA, Stanfield DP, Clarendon press, Oxford.1 and 2, 476. Pp 206-209.

Okoli, BJ (2010). Antimicrobial activity of the phytochemical constituent of Chrysophyllum albidum (African star apple) plant. J. Res. Int. Dev. (8):1-5.

Okafor, JC; Fernendes, ECM (1987). Compound farms of south-east Nigeria a predominant agroforestry home system with crops and small livestock. Agrofor Syst. 5:153-168.

Rush, D (2000). Nutrition and maternal mortality in the developing world. Am. J. Clin. Nutr. 72:2125-2405.

Ukana. DA; Aniekan, EA; Godwin, NE (2012). Evaluation of Proximate Compositions and Mineral Elements in the Star Apple Peel, Pulp and Seed. $J$. Basic Appl. Sci. Res. 2(5)4839-4843. 